\title{
Oxidation Ditch Algae Reactor (ODAR) for Nutrient and Pathogen Removal in Grey Water System
}

\author{
Aulia Ulfah Farahdiba ${ }^{1}$ \\ Department of Environmental Engineering \\ Universitas Pembangunan Nasional "Veteran" Jawa Timur \\ Surabaya, Indonesia \\ 1auliaulfah.tl@upnjatim.ac.id
}

\author{
Rian Nurrohman, Andisvina Desliani, Any Juliany \\ Department of Environmental Engineering \\ Universitas Islam Indonesia \\ Yogyakarta, Indonesia
}

\begin{abstract}
Oxidation Ditch Algae Reactor (ODAR) is a wastewater treatment reactor utilizing symbiosis between algal cultures and bacteria. ODAR reactors have large circular basin equipped with aerators. Pathogenic Escherichia coli is believed to mostly live in the contaminated area, which it could influence human health. This research conducted to analyze the performance of ODAR to remove nutrient and Escherichia Coli in grey water and artificial wastewater system. The study was conducted for $\mathbf{2 6}$ days with two batches: grey water and artificial wastewater with a mixture of fertilizer and sugar. Algae cell is measured with chlorophyll-a. Nutrient as ammonia and phosphate was measured. $E$ coli removal was analyzed as MPN/100mL. Environmental condition parameter such as $\mathbf{p H}$, dissolved oxygen, and light intensity to determine the mayor consequent of nutrient and $E$ coli removal. The results showed ODAR capability to reduce ammonia and phosphat 2 in grey water by $53,58 \%$ and $41,15 \%$ with the initial concentration 4,14 $\mathrm{mg} / \mathrm{l}$ and $2,43 \mathrm{mg} / \mathrm{l}$. As for the artificial wastewater, the removal efficiency for ammonia and phosphate is $59,7 \%$ and $59,15 \%$ with the initial concentration $23,68 \mathrm{mg} / \mathrm{l}$ and $20,50 \mathrm{mg} / \mathrm{L}$. Removal of $E$ coli due to a lack of nutrients or organic compounds and high light exposure. This is strengthened by its existence of increasing chlorophyll concentration. $E$ coli concentration decrease on grey water reached $98 \%$ and the artificial wastewater by $72 \%$. This demonstrates the ability of Oxidation Ditch Algae Reactor (ODAR) in reducing the concentration of Escherichia Coli is reached within about 6 days.
\end{abstract}

Keywords-algae; chlorophyll-a; Escherichia coli; Grey Water

\section{INTRODUCTION}

Wastewater treatment systems using algae have been developed where microalgae can contribute to BOD and COD treatment processes, decrease pathogens, eliminate nutrients, and disinfect air [1].Wastewater treatment using algae can not only be used as a substitute for certain substances. As a medium, air is also a nutritional nutrient for algae. Algalbacterial symbiosis system is known as a classic water selfpurification process in natural water. Microalgae was reputable as one of the treatment of industrial, municipal and agricultural wastewaters by [2;3]. Microalgal-bacterial processes constitute a sustainable and cost-effective alternative to conventional technologies due to their free oxygenation potential and efficient nutrient removal [4].
One of the applications of microalgae is to use Oxidation Ditch Algae Reactor (ODAR) which is a wastewater treatment plant as a ditch with a channel. Oxidation Ditch is a treatment technology that are used to treat wastewater by utilizing oxygen (aerobic conditions). Widely used in wastewater treatment due to their simple construction, low. The noble function is to reduce the bacterial content in wastewater after processing [2;5].

Algae have a relationship with bacteria that work to reduce levels of pollutants in wastewater. [1] Argued that algae and bacteria have mutually beneficial relationships, namely $\mathrm{CO}_{2}$ and $\mathrm{O}_{2}$ which are needed for algae and bacterial respiration. $\mathrm{CO}_{2}$ from bacteria is useful for the growth of algae and $\mathrm{O}_{2}$ from algae activity is beneficial for bacterial growth.

The performance of algae on the removal of fecal bacteria in wastewater treatment ponds and wetlands are developed in many research and literature. Bacteria could attachment to the morphology of Algal in water stream as suspended matter will develop of aggregates [6].

Escherichia coli is a bacterium originating from feces and frequently as bioindicator the presence of fecal contamination in water or soil, as the possible presence of pathogenic microorganisms such as E.coli.

Previous studies, developed that the release of organic contont from algae, can enhance coliform growth and enhance the endurance [7]. However coliforms may uptake the carbon and energy sources for the survival and growth from the algal degradation. This states that degradation of algal cells may impair disinfection process in living algae in the water stream [6].

The aims of this study to determine removal of nutrient and pathogen bacteria such as Escherichia Coli in wastewater with biological processing using non-selective algae to determine its ability in Oxidation Ditch Algae Reactor (ODAR).

\section{RESEARCH METHODS}

\section{A. Research Time and Location}

This research conducted in front of Biotechnology Laboratory with direct sunlight. Parameter is analyzed at Biotechnology Laboratory and Water Quality Laboratory, Islamic University of Indonesia. 


\section{B. Algae Culture}

Algae was cultivated from the green pond at Kaliurang KM.23, Yogyakarta. This pond existence as a natural environment. The green pond generally has algae blooming in the middle of the sunny season, while this research conducted.

\section{Seeding and Acclimatization}

Seeding and acclimatization process developed to receive an optimum chlorophyll-a concentration. Chlorophyll-a is the comprehensive measurement to predict the existence of green algae [2]. Majority algae was analyzed with the Biological Binocular CX-22 Olympus Philippines microscope. In the seeding process, NPK (Nitrogen, Phosphorus, and Kalium) fertilizer was added as a nutrient for microalgae with \pm 35 $\mathrm{mg} / \mathrm{L}$ every day. Seeding and acclimation process was carried out for two weeks by observing algal growth with algal cell density calculations.

\section{Experimental Setup}

Design of experiment in this research is to develop the performances of Escherichia Coli removal. Environment condition in the reactor tested with: dissolved Oxygen, light exposure, $\mathrm{pH}$, and temperature. Aeration is carried out in Oxidation Ditch with an aerator brush mounted on the reactor. Testing is carried out every 3 days for 13 days on a laboratory scale in reactors with gray water and artificial waste (grey water quality baseline).

In this study conducted using 2 types of gray water wastewater. The first study used gray water wastewater taken from integrated canteen wastewater from the Islamic University of Indonesia. Subsequent research used artificial wastewater using clean water which added nutrients in the form of NPK fertilizer with grey water quality baseline.

The research was conducted using oxidation ditch reactor with design can be seen in Picture 1 . The reactor used has a capacity of $300 \mathrm{~L}$ with an aerator rotation of 61 revolutions per minute (rpm) with batch system. The reactor is equipped with a stirrer to increase the flow velocity and turbulence obviate algae to submerge.

Phytoplankton classification is analyzed by using a pipette to take $10 \mathrm{ml}$ of algae water sample and then put it in a centrifuge tube which is then rotated by centrifuge for 15 minutes at a speed of $2000 \mathrm{rpm}$. Then the precipitate at the base of the centrifuge tube was observed by dripping on the glass preparation, then closed using a glass object. Samples were observed with a microscope with 1600 times magnification and arranged incoming light. Observations in the form of the most dominant type of phytoplankton in the sample.

Phosphate analyze refers to SNI 06-6989.31-2005 by spectrophotometer with ascorbic acid. Ammonia $\left(\mathrm{NH}_{3}\right)$ refers to SNI 06-6989.30-2005 with a phenolic by spectrophotometer.

Escherichia Coli testing refers to the Most Probable Number (MPN) Standard Methods Total Coliform 9221. Chlorophyll-a testing refers to SNI 06-4157-1996 about testing the levels of chlorophyll-a phytoplankton in water with a spectrophotometer:

Chlorophyll- $a=((26.7(A B) \times V e)) /(V s \times L) m g / m 3(1)$

Information :

Number 26.7 $=$ Constants (corrections) in absorption

$\mathrm{A}=$ difference in optical density before acidification

$\mathrm{B}=$ difference in optical density after acidification

$\mathrm{Ve}=$ volume of the test object (1)

Vs =sample test volume (m3)

$\mathrm{L}=$ transparent part or width of cuvette $(\mathrm{cm})$

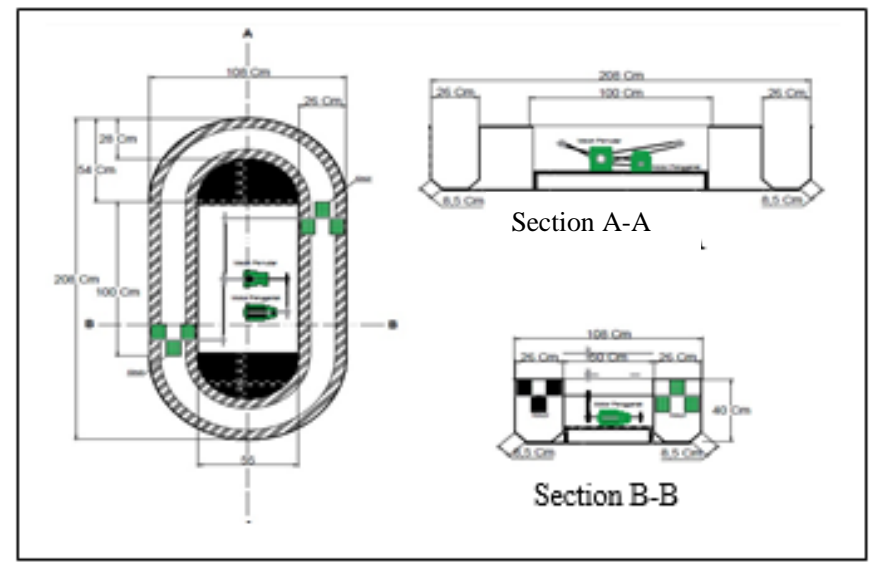

Fig. 1. Design of oxidation ditch reactor
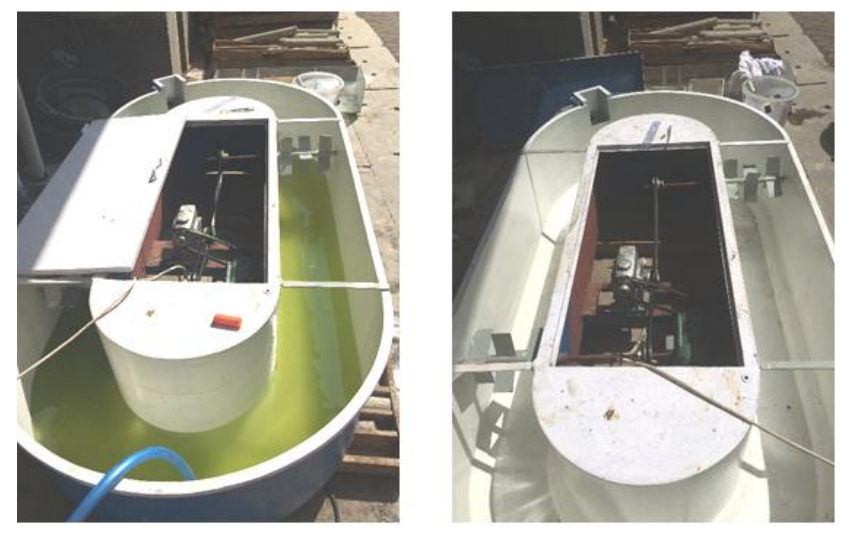

Fig. 2. ODAR reactor: Seeding and acclimatization process (left), and preparation (right)

\section{E. Data Analysis}

Correlation test to determine the relationship of data obtained from variables with test parameters. In addition, it can also be known the relationship pattern of the condition of the reactor. 


\section{RESEARCH AND DISCUSSION}

\section{A. Seeding and Acclimatization}

Running is conducted after the chlorophyll-a concentration in each reactor is seen visually high enough and have an adequate concentration of chlorophyll. Oxidation Ditch Algae Reactor obtained a value of $0.743 \mathrm{mg} / \mathrm{L}$. According to [5], the chlorophyll-a concentration of $0.6 \mathrm{mg} / \mathrm{L}$ could be developed for a running process.

\section{B. Microalgae Identification}

The results of observations using a microscope with a magnification of $1600 x$ obtained the most dominant type of algae is the type of green algae Chlorella sp. Chlorella sp. is a single-celled (unicellular) algae, microscopic in size, with a cell diameter measuring 2-8 micrometers, round like a ball and ovoid. Morphological features have thin cell walls such as spheres. Cell diameters between $2 \mu \mathrm{m}$ to $10 \mu \mathrm{m}$. Solid green at the main cell which shows a single parietal content of chloroplasts that almost fill the entire cell (this shows the classification of green algae. In addition, several studies analyze while Chlorella sp. has a considerable to remove emerging contaminant in wastewater [2;8]. Figure 3 is shown the natural dominant algae for culture.

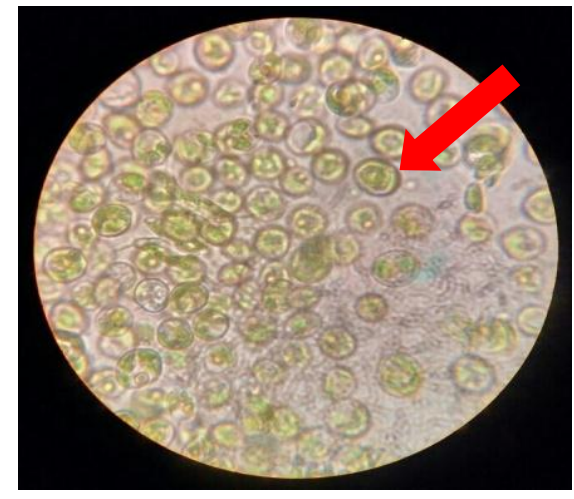

Fig. 3. Dominant algae species

\section{Grey Water Quality and Artificial Wastewater}

A primary test has been conducted to analyze the concentration of water quality parameters. Water quality of wastewater before doing research as shown in Table 1 .

TABLE I. GREY WATER AND ARTIFICIAL WASTEWATER QUALITY

\begin{tabular}{|l|l|c|c|}
\hline \multicolumn{1}{|c|}{ Quality } & \multicolumn{1}{|c|}{ Units } & Greywater & Artificial \\
\hline $\begin{array}{l}\text { Escherichia } \\
\text { Coli }\end{array}$ & $\mathrm{MPN} / 100 \mathrm{ml}$ & 460 & 20 \\
\hline Klorofil - a & $\mathrm{mg} / \mathrm{L}$ & 0,1 & 0,48 \\
\hline $\mathrm{TSS}$ & $\mathrm{mg} / \mathrm{L}$ & 75 & 188 \\
\hline $\mathrm{DO}$ & $\mathrm{mg} / \mathrm{L}$ & 10 & 11.6 \\
\hline $\mathrm{pH}$ & & 6 & 6.02 \\
\hline $\begin{array}{l}\text { Intensitas } \\
\text { Cahaya }\end{array}$ & $\mathrm{Lux}$ & 3980 & 6250 \\
\hline Temperatur & ${ }^{\circ} \mathrm{C}$ & 30 & 30 \\
\hline
\end{tabular}

\section{Dissolved Oxygen (DO), pH, and Light Intensity}

The decay of E. coli through the chemistry process in the water might affected with algae. Algal photosynthetic activity could in increased oxygenation concentration. But respiration and continuously of organic matter oxidation may also affect the DO concentration [6].

Dissolved oxygen (DO) is expressed in Picture 4. Its mean value for the reactor in $12.33 \mathrm{mg} / \mathrm{L}$. ODAR is reactor which complicated phase interactions and transformations in an OD system include transfer of dissolved oxygen from the gas phase, and carbon oxidation, nitrification and denitrification in the liquid and solid phases [5]. Therefore, definitely hypothesis should be difficult.

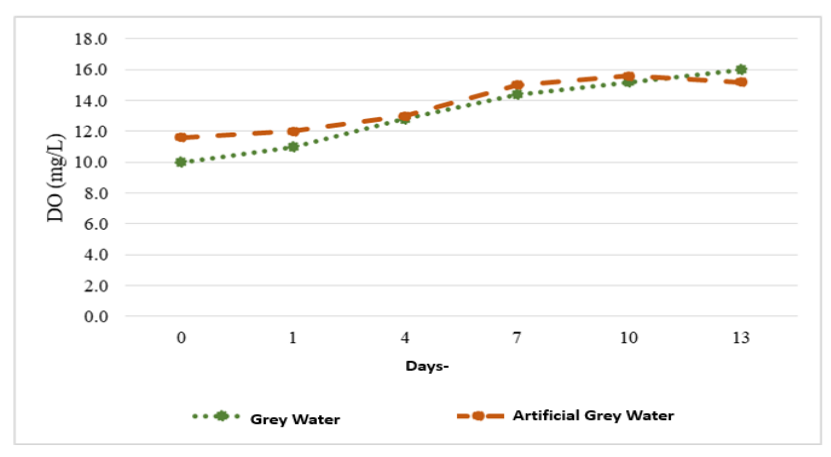

Fig. 4. Performance of dissolved oxygen condition in ODAR

The approach of this reactor, could be define the relationship between algae and bacteria. This is because the algae contained in the reactor produce oxygen through photosynthesis. Increasing of chlorophyll believed will increases the dissolved oxygen due to the process of photosynthesis while photosynthesis absorbs the carbon dioxide gas and produces oxygen. Oxygen produced by algal photosynthesis can be utilized as an electron acceptor for heterotrophic bacteria to degrade organic substances, including organic wastes [1].

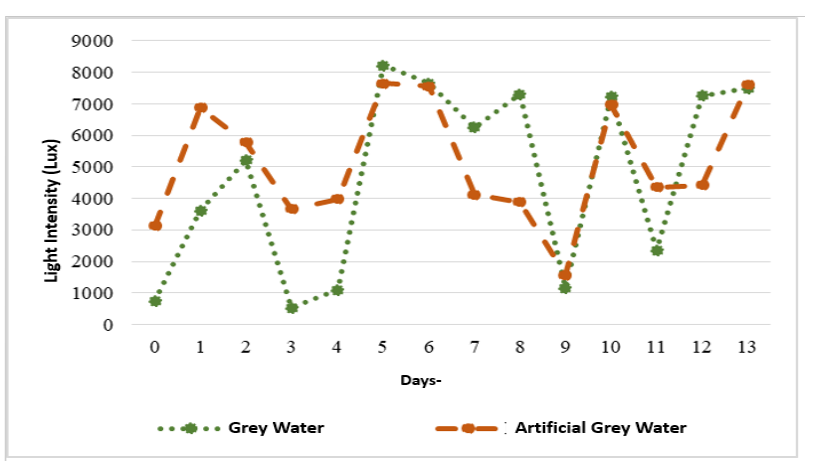

Fig. 5. Performance of Light intensity in ODAR

The chemical composition of the algal-bacterial biomass generated the changes in operational conditions identical with light exposure. According to [4], light intensity could impact the alga-bacteria symbiosis. This fact could have been caused by the higher influence of other factors such as lower light irradiances. Lights of wavelengths greater than $500 \mathrm{~nm}$ inactivates E. coli mainly through photo-oxidation which is 
entirely oxygen dependent $[6 ; 9 ; 10]$. Figure 5 is shown the light intensity in ODAR.

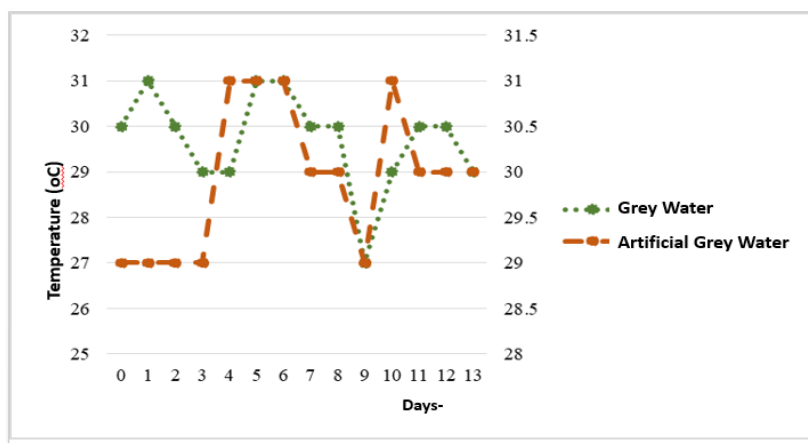

Fig. 6. Temperature condition in ODAR

Figure 6 is shown the temperature fluctuations that occur due to differences in wastewater. The observations showed that there was an increase and decrease in temperature in gray water and artificial wastes with values that tended to be stable in the sunny weather (warm temperature). The results of the range of average temperature values during the day are 27$31^{\circ} \mathrm{C}$. According to [11], the average water temperature ranges from $24-32^{\circ} \mathrm{C}$ so that in this range plankton can grow and reproduce optimum. However, microalgae may disserve affect bacterial activity by increasing the $\mathrm{pH}$ or culture temperature, or by releasing inhibitory metabolites [2].

\section{E. Microalgae Growth (Chlorophyll-a)}

The Chlorophyll-a (Chl-a) content was detected to characterize algal growth in ODAR. Chl-a concentration showed increased trend during the whole operation period. Chlorophyll-a concentration from day 0 to day 13 has a value of $0.10 \mathrm{mg} / \mathrm{L}$ to $0.59 \mathrm{mg} / \mathrm{L}$ in the reactor with gray water waste. This increase was almost five times from initial value, which means that the growth of algae in water is quite significant.

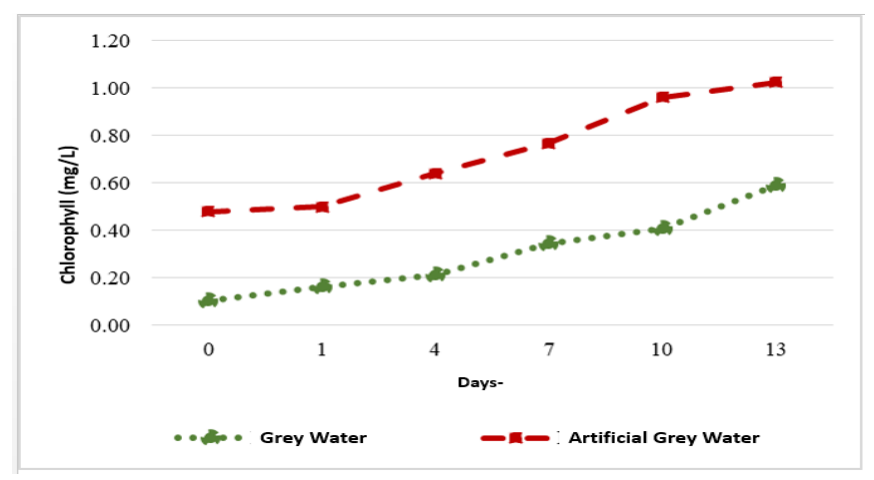

Fig. 7. Performance of Chlorophyll-a in ODAR

Artificial wastewater using NPK fertilizer showed increased in chlorophyll-a concentration from day 0 to day 13 has a value of $0.48 \mathrm{mg} / \mathrm{L}$ to $1.03 \mathrm{mg} / \mathrm{L}$ in the reactor with artificial waste. Grey water may has many factors that interfere with algal growth like unneeded substances that can interfere with the absorption of nutrients for algae in the reactor [12]. While, algae addition could enhance nutrients removal through algae growth and uptake and improve microbial activity of bacteria $[3 ; 13]$.

\section{F. Removal of Amonia $\left(\mathrm{NH}_{3}\right)$}

The reactors with grey water have lower ammonia residues compared to artificial reactors. This is because the concentration of ammonia in artificial waste is higher than that of an artificial reactor. To decrease the results of the analysis of the value of nitrate $\left(\mathrm{NH}_{3}\right)$ can be seen from Figure 8 and Figure 9.

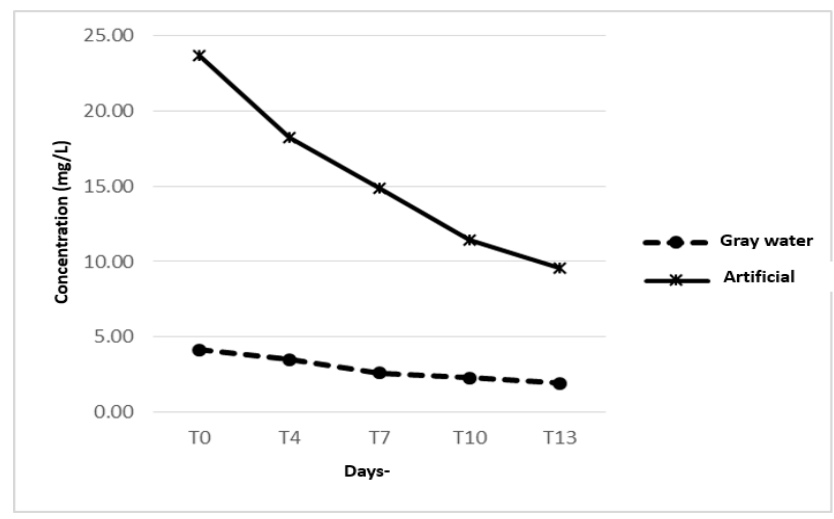

Fig. 8. Amonia Concentration in ODAR

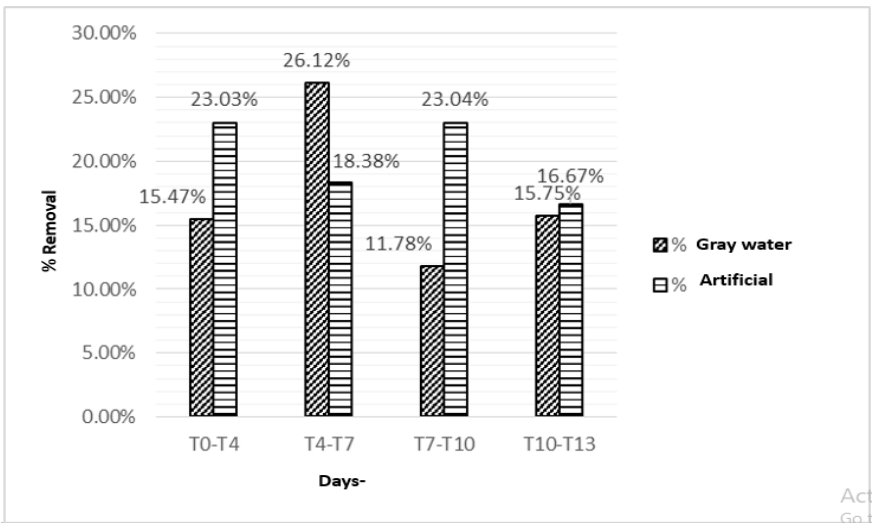

Fig. 9. Performance of Amonia Removal in ODAR

This shows that in each reactor the ammonia degradation process $\left(\mathrm{NH}_{3}\right)$ has been successful even though from the beginning the waste used is different. As stated by [2]. Nutrients ( $\mathrm{N}$ and $\mathrm{P}$ ) are the raw materials for algae metabolism that will be used during their lifetime. In addition, bacteria also play a role in reducing nutrients. Based on previous study [14], the form of nitrogen is transformed (some involving microbiology and the others are not) as part of the nitrogen cycle.

\section{G. Removal of Phosphat $\left(\mathrm{PO}_{4}\right)$}

Previous studies developed the efficiency of the decline was lower than the previous study by $[2 ; 15]$, which was able to reduce up to $43 \%$ with an average initial concentration of 0.82-6.6 mg/L. Figure 10 and Figure 11, are shown the performance of phosphate in ODAR. 


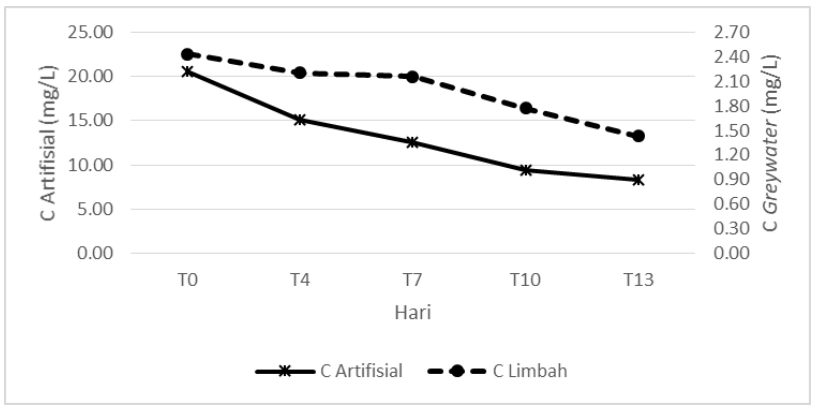

Fig. 10. Phosphate Concentration in ODAR

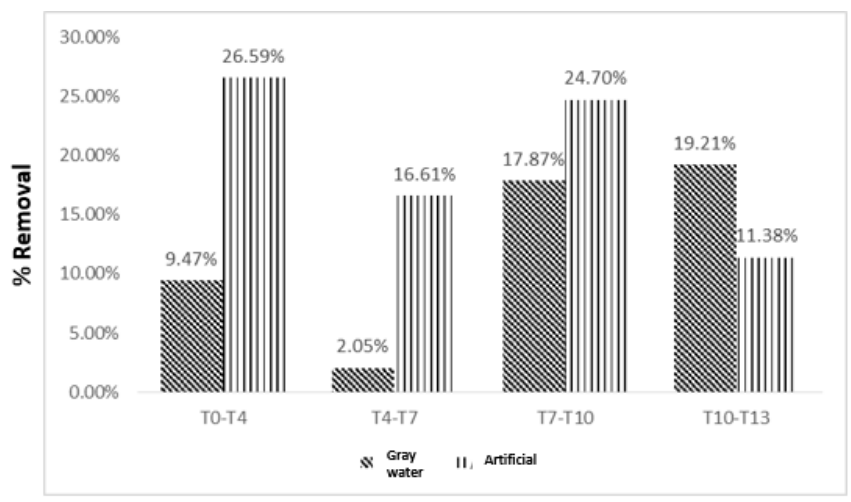

Days-

Fig. 11. Performance of Phosphate Removal in ODAR

\section{H. Correlation Chlorophyll-a and Nutrient}

Chlorophyll-a have increasing while nutrient decreasing slightly. This is because the nutrients contained in water are absorbed by algae as material for metabolism. As stated by [2], $\mathrm{PO}_{4}$ and $\mathrm{NO}_{3}$ are nutrients that are important for the growth and metabolism of phytoplankton which are indicators for evaluating the aquatic quality.

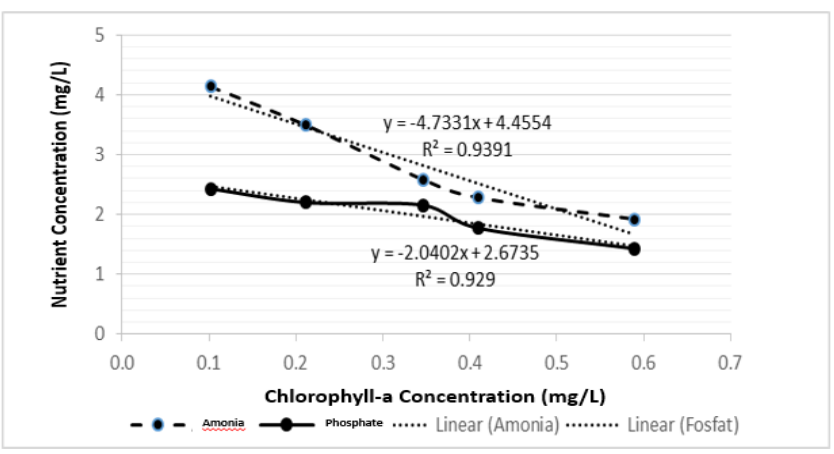

Fig. 12. Correlation between Chlorophyll-a and Nutrient removal in Grey water

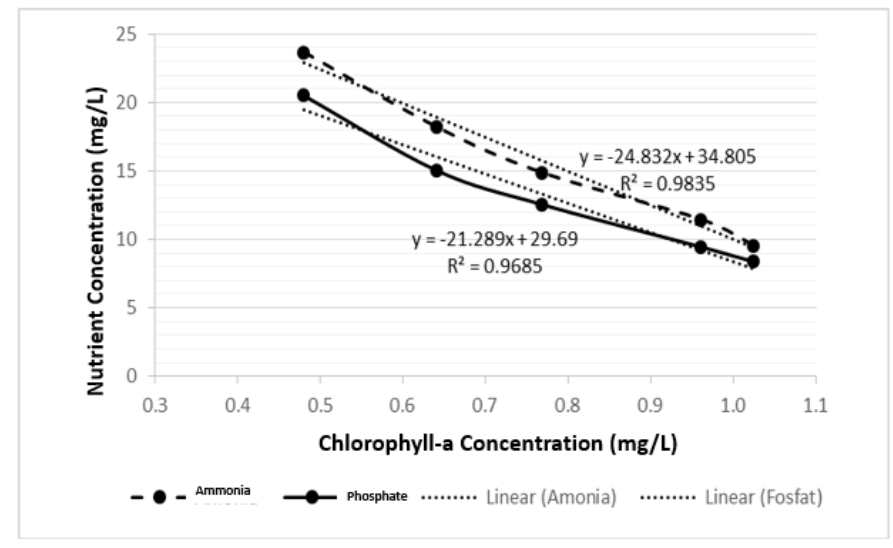

Fig. 13. Correlation between Chlorophyll-a and Nutrient removal in Artificial Grey Water

\section{Removal of E. Coli}

The results showed a decrease of E-Coli with gray water e by $98 \%$ and with artificial decreased by $72 \%$ shown in Table 2. Declining of E-Coli may be caused due to the influence of lack of nutrients and organic compounds and an increase in the concentration of light received by algae and the optimal concentration of chlorophyll-a in the reactor [16]. Further discussion will be emphasize in correlation chlorophyll-a and E-coli removal.

TABLE II. E.COLI ANALYSIS

\begin{tabular}{|c|c|c|}
\hline Days- & $\begin{array}{c}\text { Greywater } \\
\text { (MPN/100ml) }\end{array}$ & $\begin{array}{c}\text { Artificial } \\
(\text { MPN/100ml })\end{array}$ \\
\hline 1 & 460 & 20 \\
\hline 7 & 160 & 11,0 \\
\hline 13 & 9,3 & 5,60 \\
\hline
\end{tabular}

\section{J. Correlation between E.coli Removal and Chlorophyll-a}

Correlation graphs shown in Figures 14 and Figure 15 increase chlorophyll-a concentration in algae which can cause a decrease in Escherichia Coli decay rate. Correlation between Escherichia Coli and chlorophyll-a with grey water and artificial waste wastes obtained correlation values of 0.8889 and 0.9826 respectively.

The previous study showed, the concentrations and prevalence of total and pathogenic $V$. parahaemolyticus, increased significantly of algae biomass. This is upon the exposure to DOM originating from phytoplankton. DOM is the primary energy source for bacteria in the ocean and phytoplankton are the primary source of ocean organic matter. However, pathogen bacteria will decreasing if the temperature higher performance [17]. 


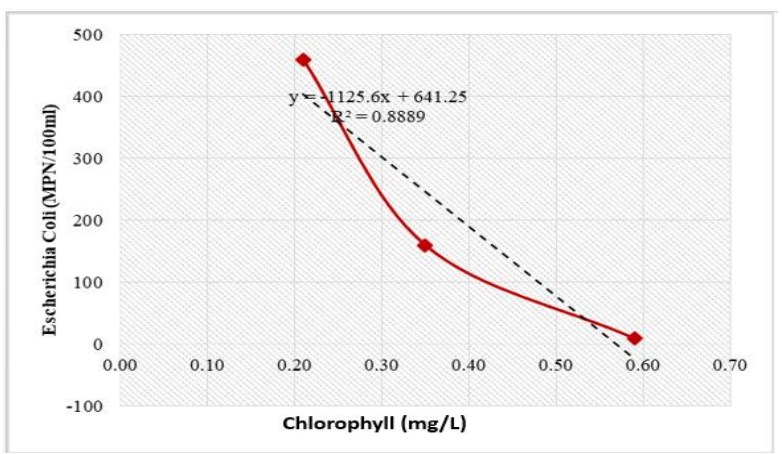

Fig. 14. Correlation between Chlorophyll-a and E-coli removal in Grey water

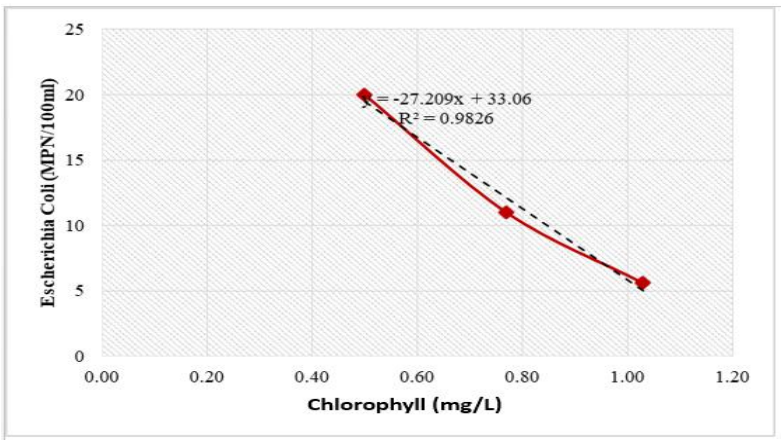

Fig. 15. Correlation between Chlorophyll-a and E-coli removal in Artificial Greywater

According to [6], algae are significantly remove E. coli bacteria in eutrophic lakes through increased oxygenation and $\mathrm{pH}$ elevation. Under laboratory conditions, as chlorophyll a concentration increases in light, an optimum chlorophyll a concentration of $0.24 \mathrm{mg} / \mathrm{L}$ is reached after which rate of decay of E. coli decreases. The experiment of [6] has similarity results of this research.

\section{K. Correlation Between Light Intensity and E.Coli Removal}

Correlation graph it shown in Figures 16 and 17 where there was an increase in the concentration of light from the previous to the end of the study to adjust the activity of E.Coli bacteria. Generally light, has destructive power on cells of microorganisms that do not have photosynthetic pigments. While light with short waves can affect the living body.

Previous study developed that E.coli survival rates are dependent on temperature in the water [18]. Sunlight affects the growth of E.Coli, the longer the time of exposure to sunlight, the lower the number of E-Coli bacteria colonies. Sunlight intensity $[11 ; 19]$ have also been found to affect E. coli survival in waters.

However, that E. coli survival rates within process in biological and physical factors could be the explanation. The microbial ecosystem composition can affect E.Coli survival. Grazing by zooplankton and micro plankton, toxic algal products and other toxins, along with various chemical and physical factors are commonly mentioned as reasons for decreased E.coli numbers in untreated surface waters [9].

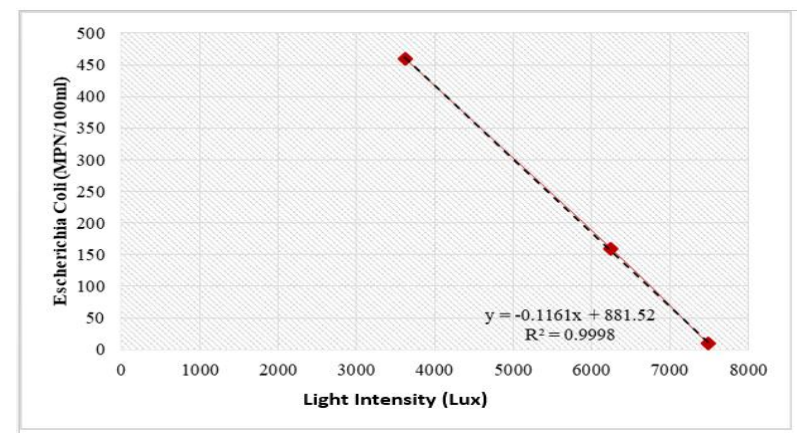

Fig. 16. Correlation between E-coli and ligt intensity in grey water

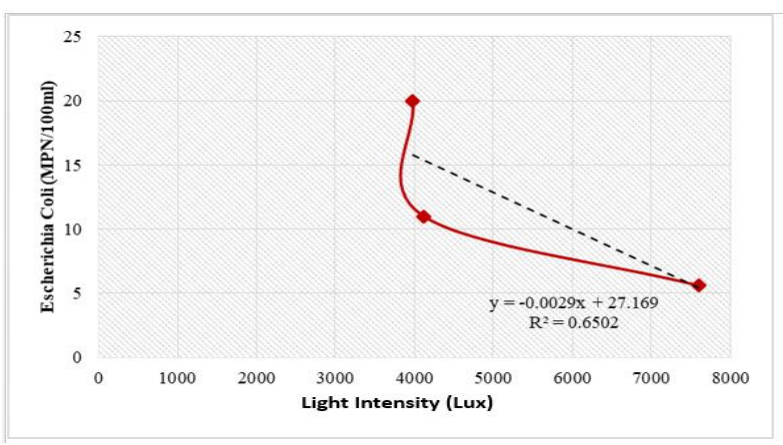

Fig. 17. Correlation between E-coli and ligt intensity in artificial grey water

The indirect effect of water biota on E. coli survival was demonstrated by [12], suggested that the content of dissolved carbon dioxide could be indicator to the numbers of E.coli.

It can be seen that the correlation between Escherichia Coli and light with gray water and artificial waste is obtained by the correlation values of 0.9998 and 0.6502 , respectively, indicating that the greater the concentration of light, the smaller the growth of Escherichia Coli in the reactor.

\section{CONCLUSION}

1. Research show the ability of Oxidation Ditch Algae Reactor (ODAR) to reduce levels of ammonia ( $\left.\mathrm{NH}_{3}\right)$ and phosphate $\left(\mathrm{PO}_{4}\right)$ in grey water by $53.58 \%$ and $41.15 \%$, respectively, while in artificial grey water $59.70 \%$ to $59.14 \%$.

2. The ability of ODAR in reducing the concentration of Escherichia Coli in grey water waste by $98 \%$, while in artificial waste (grey water) by $72 \%$.

3. Light can significantly reduce the growth of Escherichia Coli in the reactor, while chlorophyll-a may be induce effect of E.coli removal.

\section{REFERENCES}

[1] A. Kouzuma and K. Watanabe, "Exploring the potential of algae/bacteria interactions," Curr. Opin. Biotechnol., vol. 33, pp. 125$129,2015$.

[2] L. Zhu, "Nutrient removal and biodiesel production by integration of freshwater algae cultivation with piggery wastewater treatment," Water Res., vol. 47, no. 13, pp. 4294-4302, 2013.

[3] C. S. Lee, S. A. Lee, S. R. Ko, H. M. Oh, and C. Y. Ahn, "Effects of photoperiod on nutrient removal, biomass production, and algal-bacterial 
population dynamics in lab-scale photobioreactors treating municipal wastewater," Water Res., vol. 68, pp. 680-691, 2015.

[4] E. Posadas, M. Morales, C. Gomez, F. G. Acién, and R. Muñoz, "Influence of $\mathrm{pH}$ and $\mathrm{CO} 2$ source on the performance of microalgaebased secondary domestic wastewater treatment in outdoors pilot raceways," Chem. Eng. J., vol. 265, pp. 239-248, 2015.

[5] L. Lei and J. Ni, "Three-dimensional three-phase model for simulation of hydrodynamics, oxygen mass transfer, carbon oxidation, nitrification and denitrification in an oxidation ditch," Water Res., vol. 53, pp. 200214, 2014.

[6] E. D. O. Ansa, H. J. Lubberding, J. A. Ampofo, and H. J. Gijzen, “The role of algae in the removal of Escherichia coli in a tropical eutrophic lake," Ecol. Eng., vol. 37, no. 2, pp. 317-324, 2011.

[7] D. H. Cho et al., "Organic carbon, influent microbial diversity and temperature strongly influence algal diversity and biomass in raceway ponds treating raw municipal wastewater," Bioresour. Technol., vol. 191, pp. 481-487, 2015

[8] B. T. Higgins and J. S. VanderGheynst, "Effects of Escherichia coli on mixotrophic growth of Chlorella minutissima and production of biofuel precursors," PLoS One, vol. 9, no. 5, 2014.

[9] I. Barcina, I. Arana, J. Iriberri, and L. Egea, "Factors affecting the survival of E. coli in a river," Hydrobiologia, vol. 141, no. 3, pp. 249253, 1986.

[10] H. DERABE-MAOBE, "High rate algal pond for greywater treatment in arid and semi-arid areas," 2014.

[11] C. M. Davies and L. M. Evison, "Sunlight and the survival of enteric bacteria in natural waters," J. Appl. Bacteriol., vol. 70, no. 3, pp. 265274, 1991.

[12] E. A. Gray, "Survival of Escherichia-Coli in Stream Water in Relation to
Carbon-Dioxide and Plant Photosynthesis," J. Appl. Bacteriol., vol. 39 , no. 1 , pp. 47-54, 1975.

[13] C. C. Tang, W. Zuo, Y. Tian, N. Sun, Z. W. Wang, and J. Zhang, "Effect of aeration rate on performance and stability of algal-bacterial symbiosis system to treat domestic wastewater in sequencing batch reactors," Bioresour. Technol., vol. 222, pp. 156-164, 2016.

[14] R. Craggs, D. Sutherland, and H. Campbell, "Hectare-scale demonstration of high rate algal ponds for enhanced wastewater treatment and biofuel production," J. Appl. Phycol., vol. 24, no. 3, pp 329-337, 2012.

[15] E. Gnansounou and J. Kenthorai Raman, "Life cycle assessment of algae biodiesel and its co-products," Appl. Energy, vol. 161, pp. 300-308, 2016.

[16] J. J. Cole, "Interactions Between Bacteria and Algae in Aquatic Ecosystems," Ecol. Syst., vol. 13, pp. 291-314, 1982

[17] J. D. Thickman and C. J. Gobler, "The ability of algal organic matter and surface runoff to promote the abundance of pathogenic and nonpathogenic strains of Vibrio parahaemolyticus in Long Island Sound, USA," PLoS One, vol. 12, no. 10, pp. 1-18, 2017.

[18] R. A. Blaustein, Y. Pachepsky, R. L. Hill, D. R. Shelton, and G. Whelan, "Escherichia coli survival in waters: Temperature dependence," Water Res., vol. 47, no. 2, pp. 569-578, 2013.

[19] L. W. Sinton, C. H. Hall, P. a Lynch, and R. J. Davies-Colley, "Sunlight Inactivation of Fecal Indicator Bacteria and Bacteriophages from Waste Stabilization Pond Effluent in Fresh and Saline Waters Sunlight Inactivation of Fecal Indicator Bacteria and Bacteriophages from Waste Stabilization Pond Effluent in Fresh and," Appl. Environ. Microbiol., vol. 68 , no. 3, pp. 1122-1131, 2002. 